\title{
Hoyem v. Manhattan Beach City School District: School District Liability for Injuries to Truants
}

In Hoyem v. Manhattan Beach City School District, ${ }^{1}$ a divided California Supreme Court held that a school district may be liable for offcainpus injuries to a truant if proximately caused by negligent on-campus supervision. The majority relied on Dailey v. Los Angeles Unified School District, ${ }^{2}$ which held that a school district has a duty to provide reasonable on-campus supervision and to enforce rules necessary for student safety. The court concluded that California Education Code section 44808's grant of school district immunity for off-cainpus student mjuries is inapplicable when the school district has not exercised reasonable care in supervision.

The case is set fortli briefly in Part I. Part II suggests that the probleins engendered by the Hoyem approach outweigh the policy considerations that would support liability, and argues that there should be no duty to supervise agamst truancy. Part III questions the court's statutory analysis and argues that section 44808 should liave been interpreted to absolve school districts of liability for off-campus injuries to truants. Part IV suggests legislative action that could serve as a compromise between Hoyem liability and complete immunity.

\section{THE CASE}

Ten-year-old plaintiff Michael Hoyem left his elementary school premises without permission prior to the end of classes. Four blocks away he was struck by a inotorcycle and seriously injured. ${ }^{3}$ Filing suit

1. 22 Cal. 3d 508, 585 P.2d 851, 150 Cal. Rptr. 1 (1978) (Tobriner, J.) (4-3 decision).

2. 2 Cal. 3d 741, 470 P.2d 360, 87 Cal. Rptr. 376 (1970).

3. A short time after the accident Michael's mother, Mary Ann Hoyem, saw him in the hospital and allegedly suffered emotional and physical imjuries from the shock. The court's treatment of this claim is beyond the scope of this Note, but it does appear that the court's unanimous denial of the claim is consistent with current Califormia decisions. See Justus v. Atchison, 19 Cal. 3d 564, 582-85, 565 P.2d 122, 134-36, 139 Cal. Rptr. 97, 109-11 (1977); Powers v. Sissoev, 39 Cal. App. 3d 865, 874, 114 Cal. Rptr. 868, 874 (2d Dist. 1974); Deboe v. Horn, 16 Cal. App. 3d 221, 94 Cal. Rptr. 77 (2d Dist. 1971). Some commentators suggest that the court reexamme its requirement that there be actual observation of the accident for recovery. See Levy \& Ursin, Tort Law in California: At the Crossroads, 67 CALIF. L. REv. 497, 526-27 (1979). 
against the defendant school district, ${ }^{4}$ he alleged that his injuries had been proximately caused by the school district's negligent supervision. The trial court sustained defendant's deinurrer to plaintiff's third anended complaint witliout leave to amend.

The supreme court reversed the trial court's dismissal of Michael's cause of action, holding that if a jury were to decide that the defendant's supervision was negligent and proximately caused plaintiff's injuries, ${ }^{5}$ then the scliool district would be liable.

The majority argued that school officials have a duty to prevent off-campus injuries by containing students on school grounds. ${ }^{6}$ It further argued that the legislature did not intend the statute absolving school districts of liability for off-campus injuries to apply to negligently supervised students.

\section{II}

\section{The Duty Issue}

\section{A. Prior Case Law}

Liability for on-campus injuries resulting from negligent supervi$\operatorname{sion}^{7}$ has existed for many years in California. Nevertheless, the supreme court has established that a school district is not an insurer of its students' safety. ${ }^{8}$ In its most recent decision concerning supervision of students, Dailey v. Los Angeles Unified School District, ${ }^{9}$ the court

4. A separate action was brought against the motorcycle driver, but the court did not discuss his liability. 22 Cal. 3d at 512 n.l, 585 P.2d at 853 n.1, 150 Cal. Rptr. at 3 n.1.

5. The plaintiff must first demonstrate that the district's negligence was the "but for" cause of the truancy. Failure to provide supervision which would have psychologically dissuaded a student from becoming truant could be considered a "but for" cause. Cf. Dailey v. Los Angeles Unified School Dist., 2 Cal. 3d 741, 750 n.7, 470 P.2d 360, 365 n.7, 87 Cal. Rptr. 376, 381 n.7 (1970) (recognizing that students avoid inisconduct knowing that teachers may be nearby, even though the students are not under constant surveillance).

6. The majority also argued that prior California cases have held school districts liable for off-campus injuries. 22 Cal. 3d at 514-15, 585 P.2d at 854-55, 150 Cal. Rptr. at 4-5. Yet, none of these cases involved truancy.

The court cited Satariano v. Sleight, 54 Cal. App. 2d 278, 129 P.2d 35 (1st Dist. 1942), where a student was injured crossing a public street dividing the campus. However, it seems illogical to assert that a student proceeding from one portion of campus to another has gone "off-campus" by setting foot on a public street that he is required to cross. The Satariano court itself viewed the injury as effectively occurring on school grounds. Id. at 284, 129 P.2d at 39.

7. See generally Mancke, Liability of School Districts for the Negligent Acts of Their Employ. ees, 1 J. of L. \& Educ. 109 (1972); Seitz, Legal Responsibility Under Tort Law of School Personnel and School Districts as Regards Negligent Conduct Toward Pupils, 15 Hastings L.J. 495 (1964); Annot., 38 A.L.R.3d 830 (197I).

8. See, e.g., Taylor v. Oakland Scavenger Co., 12 Cal. 2d 310, 317, 83 P.2d 948, 951 (1938).

9. 2 Cal. 3d 741, 470 P.2d 360, 87 Cal. Rptr. 376 (1970). In Dailey, a high school student died froun injuries sustained playing a forbidden gane, called "slap-boxing," near the school gyın without supervision during the lunch hour. The school district was held liable for proximatcly causing the death due to negligent supervision. 
held that school authorities have a duty to supervise students on-campus and an accompanying duty to enforce rules and regulations necessary for their protection. ${ }^{10}$

Liability for injuries sustained by students lawfully off-campus has received varied treatment by California courts. School districts are not liable for off-campus student injuries (1) during travel to and from school, unless the school itself provides transportation, ${ }^{11}$ and (2) during nonrequired field trips or excursions. ${ }^{12}$ Schools have been held liable for on-campus negligence that resulted in injuries on land directly adjacent to the scliool grounds. ${ }^{13}$ One court has lield that a school could be liable for failing to warn a student about a danger the student encountered off-campus. ${ }^{14}$

Hoyem is a case of first impression insofar as it concerns the liability of a school district toward a truant.

\section{B. Duty Under the Administrative Code}

In Dailey, the court had held that school authorities have a duty to supervise students on-campus and an accompanying duty to enforce rules and regulations necessary for their protection. The Hoyem majority found support for its extension of the Dailey loolding to truants in a provision of the California Administrative Code that states: "A pupil may not leave the school premises at recess, or at any other time before the regular hour for closing school, except in case of emergency, or with the approval of the principal of the school." 15 The court urged that this regulation imposed a duty on the school to prevent students from leaving the grounds, since there was "no doubt that this rule is at least in part for the pupils' protection, and that the school authorities therefore bore the duty to exercise ordinary care to enforce the rule." 16

The Hoyem court might have correctly identified the purpose of

10. Id. at 747, 470 P.2d at 363, 87 Cal. Rptr. at 379 .

11. See, e.g., Gilbert v. Sacramento Unified School Dist., 258 Cal. App. 2d 505, 65 Cal. Rptr. 913 (5th Dist. 1968).

12. Cal. Educ. Code $\$ 35330$ (West 1978). See Castro v. Los Angeles Bd. of Educ., 54 Cal. App. 3d 232, 126 Cal. Rptr. 537 (2d Dist. 1976) (district hable for death to student participating in required off-campus part of ROTC curriculum).

13. See, e.g., Raymond v. Paradise Unified School Dist., 218 Cal. App. 2d 1, 31 Cal. Rptr. 847 (3d Dist. 1963) (unsupervised bus loading zone adjacent to campus); Satariano v. Sleight, 54 Cal. App. 2d 278, 129 P.2d 35 (Ist Dist. 1942) (public street between gym and playing field).

14. Calandri v. Ione Unified School Dist., 219 Cal. App. 2d 542, 33 Cal. Rptr. 333 (3d Dist. 1963). The student in Calandri made a toy cannon in shop class. He took the cannon home where it misfired, causing him injury. The court held that the school district could be hable since "[a] jury could conclude reasonably that instruction and supervision of the making of the cannon should have included a warning as to its potentialities to nuaim and even kill . . . and of safety practices to be observed in the fusmg and firing of the cannon." Id. at 549, 33 Cal. Rptr. at 337.

15. 5 CAL. AdMIN. CODE $\S 303$ (1977).

16. 22 Cal. $3 \mathrm{~d}$ at 514,585 P.2d at 854,150 Cal. Rptr. at 4. 
section 303, but it is equally possible that the State Board of Education was not thinking about pupil safety and off-campus dangers. Simce students can be taught only if they remain on-campus and attend class, the Board may have sought to restrict students to campus simply to facilitate their education. This imterpretation would be consistent with section 303's language and has nothing to do with preventing student mjuries. ${ }^{17}$

The court overlooked the fact that section 303 , by its own terms, directs pupil conduct, not teacher conduct. ${ }^{18}$ The regulation is contamed within a subdivision titled "Duties of Pupils." Section 303 places a duty on students not to leave campus, not on teachers to prevent students from leaving. The regulation might be read to require school districts to notify pupils of their duty to remain on-campus. ${ }^{19}$ However, the court's inference of a duty to prevent truancy was not warranted by the language of the regulation.

\section{Policy Considerations}

The existence of a duty is a question of law; the court must balance policy considerations to determine whether a particular plaintiff is entitled to protection. ${ }^{20}$ In Rowland $v$. Christian, ${ }^{21}$ the court stated the fundamental principle of tort law in California that "everyone is re-

17. Ironically, the harm most clearly sought to be avoided by the statute, i.e., failure to receive an education, was rendered noncompensable by the court of appeal in Peter W. v. San Francisco Unified School Dist., 60 Cal. App. 3d 814, 131 Cal. Rptr. 854 (1st Dist. 1976). In Peter $W$, a high school graduate sued the school district for failure to discharge its statutory duty to provide an adequate education. The court stated that "the several 'enactments' [requiring that students be provided an education] have been conceived as provisions directed to the attainment of optimum educational results, but not as safeguards against 'injury' of any kind: i.e., as administrative but not protective." Id. at $826,13 \mathrm{I}$ Cal. Rptr. at 862 .

The Peter $W$. rationale suggests that teachers who negligently allow students to skip classes and leave campus, thus depriving them of their state-mandated education, may be open to administrative sanctions. In addition, to the extent that tort rccovery is designed to channel human behavior, Hoyem and Peter W. encourage school districts to concentrate on the "babysitting" aspect of school life, at the expense of efforts to provide an education.

I8. See Kerwin v. County of San Mateo, 176 Cal. App. 2d 304, 1 Cal. Rptr. 437 (1st Dist. 1959), where the court of appeal interpreted foriner CAL. EDUC. CoDE $\$ 13229$ (now $\S 44807$ ) (West 1978) which provided, "Every teacher in the public schools shall hold pupils to a strict account for their conduct on the way to and from school, on the playgrounds, or during recess." (Emphasis added by the court). The Kerwin court stated:

Plaintiff seems to confuse the italicized portion, which is the pupil's duty, with the duty of a teacher. Obviously this section does not impose a duty on the teacher or the district to supervise the pupils on their way homc. The section refers to the behavior of school children and not to their safe conduct to and from school.

176 Cal. App. 2d at 309, I Cal. Rptr. at 440.

19. The duty to notify would arise because students could not be expected to be familiar with the California Administrative Code.

20. Dillon v. Legg, 68 Cal. 2d 728, 734, 441 P.2d 912, 916, 69 Cal. Rptr. 72, 76 (1968).

21. 69 Cal. 2d 108, 443 P.2d 56I, 70 Cal. Rptr. 97 (1968). 
sponsible for an injury caused to another by his want of ordinary care or skill in the management of his [person]." ${ }^{322}$ The policy factors that should be used to determine whether there should be a departure from this general duty of ordinary care are:

the foreseeability of harm to the plaintiff, the degree of certainty that the plaintiff suffered injury, the closeness of the connection between the defendant's conduct and the injury suffered, the moral blame attached to the defendant's conduct, the policy of preventing future harm, the extent of the burden to the defendant and consequences to the commumity of imposing a duty to exercise care with resulting liability for breach, and the availability, cost, and prevalence of insurance for the risk involved. ${ }^{23}$

The Hoyem majority did not discuss the policies that might lead to a finding of duty, as it asserted that Hoyem did not expand the duty to supervise established in Dailey. ${ }^{24}$ Hoyem did, however, impose a new duty: the duty to contain students intentionally trying to leave campus. While containment is a form of supervision, it is significantly different from the traditional type of supervisorial duty imposed by Dailey and its predecessors. A level of supervision which may be quite adequate to prevent injuries on-campus may be totally inadequate to prevent truancies. A single playground supervisor able to control all horseplay and fights may be mcapable of preventing students from shpping offcampus. To the extent that increased supervision is required to constitute reasonable truancy prevention, a new duty has been imposed. ${ }^{25}$

A finding of nonliability in Hoyem would not have been contrary to the policy determination underlying Dailey. Application of the Rowland policy factors to Hoyem would indicate that the truancy situation differs significantly from that found in Dailey. It is arguably less foreseeable that a neghigently supervised student will lcave campus and becoine injured ${ }^{26}$ than that he will become exposed to on-cainpus mjury.

22. Id. at 119,443 P.2d at 568,70 Cal. Rptr. at 104 .

23. Id. at 113, 443 P.2d at 564, 70 Cal. Rptr. at 100. See also Raymond v. Paradise Unified School Dist., 218 Cal. App. 2d 1, 8, 31 Cal. Rptr. 847, 851-52 (3d Dist. 1963).

24. $22 \mathrm{Cal} .3 \mathrm{~d}$ at $523,585 \mathrm{P} .2 \mathrm{~d}$ at $854,150 \mathrm{Cal}$. Rptr. at 4.

25. A result that seems to flow logically from the Hoyem decision is that truants who leave home but never get to school may be able to sue school districts when they are imjured. In exercising reasonable supervisorial care, teachers have a duty to take attendance to ascertain whether all students are present. See 5 CAL. ADMIN. CODE $\S 400($ b) (1979). If school authorities negligently perform this duty, and the neghigence is found to be a proximate cause of the injury, then the district will be liable under Hoyem. The negligence might oceur through a failure to recognize that the student did not report to school, or through failure to act reasonably after discovering the student's absence (e.g., failing to notify parents of the student's truancy).

26. In Kerwin v. County of San Mateo, 176 Cal. App. 2d 304, 309, 1 Cal. Rptr. 437, 440 (Ist Dist. 1959), the court of appeal said: "No reason is alleged why an 11-year-old boy could not safely return home. . . . Nothing is alleged to cause defendant [school district] to beheve otherwise, or that an 11 -year-old boy would not substantially appreciate the dangers to be encountered on the streets." 
The connection between the district's conduct and an injury suffered at a remote location at the hands of a third-party driver is certainly less than the connection when the injury occurs on property owned and controlled by the school. ${ }^{27}$ It is also significant that the intentional inisconduct of truants always intervenes between the district's conduct and the injury, whereas on-campus injuries can occur when there is no knowingly improper student behavior. ${ }^{28}$ This intervention not only lessens the foreseeability of mjury, but also affects the sense of moral culpability of the school's actions. Where the defendant's fault is in preventing the plaintiff's intentional violation of rules, the defendant's culpability seems to pale beside that of the plaintiff.

The financial and supervisorial burden imposed by Hoyem is greater than that imposed by Dailey because a greater level of supervision is needed to prevent truancies. In addition, Hoyem creates a new insurance burden by expanding the class of plaintiffs who may recover from schools. This burden may be substantial, ${ }^{29}$ and is one that schools can ill afford at this time. Unlike private businesses, public schools are unable to spread increased insurance costs across society by raising prices. ${ }^{30}$ Moreover, after Proposition 13, school district funding is extremely limited, and any increased spending on insurance can therefore

27. The weakness of the connection is demonstrated by the following situation. A truant and nontruant, traveling together, could receive the same injury but only the truant may be able to resort to recovery from the school. See Note, The Modern Concept of Duty: Hoyem v. Manhattan Beach City School District and School District Liability for Injuries to Truants, 30 Hastings L.J. 1893, 1917 (1979). For example, one student may rcceive permission to walk home for lunch, while another student decides to become a truant and accompany him home. There is an equal risk of imjury to each, but the truant receives added financial protection. It is questionable whether the district's negligence should result im liability, since the district can nonnegligently subject students to exactly the same risk of harm.

28. For example, a student might negligently ride his bike on a busy playground, causing injury to himself and another student witl whom lie collides. If the district were negligent in allowing the bike riding, then the district's conduct resulted in injuries to two students, neitluer of whom imtended to break any school rules. See Buzzard v. East Lake School Dist., 34 Cal. App. 2d 316, 93 P.2d 233 (3d Dist. 1939).

29. Insurance costs for elementary school districts liave skyrocketed between 1974 and 1978. Premium payinents have grown by $345 \%$ over this period, an mcrease of $\$ 31$ million. $22 \mathrm{Cal}$. 3d at 524, 585 P.2d at 861, 150 Cal. Rptr. at 11 (Clark, J., dissenting). The scliool districts contacted in the aftermath of the decision indicated that their present plans are to self-insure against Hoyem injuries. The availability and cost of private insurance for this type of injury are unknown. The decision to self-insure may in part be due to the hope that the legislature will overturn Hoyem. See note 56 infra.

30. See Wright v. Arcade School Dist., 230 Cal. App. 2d 272, 279, 40 Cal. Rptr. 812, 815 (3d Dist. 1964): "The school district's character as a public agency is particularly significant. . . . [T] he extent of a public agency's powers, the role imposed upon it by law and the limitations imposed upon it by budget are factors which peculiarly affect the obiigation of care owed by public agencies." 
only be funded through cuts in other areas of the school's budget. ${ }^{31}$

If private insurance is too expensive or unavailable, school districts will have to protect themselves by increasing campus security. This action itself imposes additional financial and administrative burdens. Added security personnel might be hired, or the physical structures of schools might be altered to limit opportunities for escape.

There are two major drawbacks to this alternative. First, it requires a shift im personnel and expenditures from education to policing. Second, it imposes a stifling atmosphere of confinement on school campuses. As Justice Clark noted, "An enforced atmosphere of confinement and limitation on movement will also discourage off-campus and inter-campus innovative programs." 32 Perhaps more importantly, an oppressive atmosphere may alienate students and prove inimical to instilling a healtlyy learning attitude on campus. ${ }^{33}$

The very real danger of Hoyem is that school districts will overreact to the decision in order to avoid liability. Simce a jury might consider that almost anything short of a truant-proof school is less than reasonable supervision, schools may feel compelled to implement the prison-like security measures discounted by the majority. The social cost of overzealous truancy prevention is that it hinders the basic educational purpose of school. This cost, felt by all students, should outweigh the benefit to the few students who would be injured but for the tighter security that prevented their truancy. Taken together with the other policy questions implicated in Hoyem, this cost should have

31. Proposition 13 substantially lowered state and local government income by sharply reducing real property taxes. See CAL. ConST. art. XIllA.

Parents can obtain low cost accident insurance for their children if they so desire. In the San Diego Unified School District, for example, students are offered group accident insurance. The annual cost for school day coverage is $\$ 3.50$ for elementary and junior high school students, and $\$ 6.00$ for senior high school students. Coverage on a 24 -hour basis is $\$ 20.00$ per year. Letter from Ralph D. Stern, Schools Attorney, San Diego City Schools (Apr. 19, 1979) (on file at California Law Review). In Los Angeles, school day coverage costs between $\$ 3.50$ and $\$ 12.00$ per year, with 24-hour coverage costing between $\$ 18.00$ and $\$ 38.00$. While policy linits vary, maximum payable benefits range between $\$ 10,000$ and $\$ 250,000$. Letter from Richard M. Clowes, Los Angeles County Superintendent of Schools (May 21, 1979) (on file at California Law Review). See also Kimball, Compulsion Without Protection or Recourse: The Case for No-Fault Accident Insurance for School Children, 1975 UTAH L. REv. 925.

32. 22 Cal. 3d at 525, 585 P.2d at 861, 150 Cal. Rptr. at 11 (Clark, J., dissenting).

33. See generally Brookover, Schweitzer, Schneider, Beady, Flood \& Wisenbaker, Elementary School Social Climate and School Achievement, 15 AM. Educ. Research J. 301, 316-17 (1978); Cullers, Hughes \& McGreal, Administrative Behavior and Student Dissatisfaction: A Possible Relationship, 50 PEABODY J. Educ. 155, 162-63 (1973); Marrola, McGrath \& Williams, Schools: Antiquated Systems of Social Control, at 22-26 (Feb. 1978) (unpublished paper prepared for the National Council on Crime and Delinqnency) (ERIC Document Reproduction Service No. ED 157 191); Metz, The Exercise of Control in Two Midwestern Junior High Schools, 47-49 (Mar. 1976) (unpublished paper prepared for the National Institute of Education) (ERIC Document Reproduction Service No. ED 148 907). 
moved the court to determine that there was no duty to prevent truancy.

\section{III}

\section{The IMMUNITY IsSUE}

The inost disturbing aspect of the case is the court's treatinent of Califorma Education Code section 44808. The statute states in relevant part:

[N]o school district . . . shall be responsible or in any way liable for the conduct or safety of any pupil of the public schools at any time when such pupil is not on school property, unless such district . . . has undertaken to provide transportation for such pupil to and from the school premises, has undertaken a school-sponsored activity off the premises of such school, has otlerwise specifically assumed such responsibility or liability or has failed to exercise reasonable care under the circumstances. ${ }^{34}$

The defendant school district argued that since Michael Hoyem was "not on school property" when injured, the statutory immunity barred recovery. The court, however, held that Hoyen's allegation of negligent supervision brought the case within the last clause of the statute's exceptions to immunity.

The court's statutory interpretation is doubtful. The court decided that the legislature intended to grant immunity only when a district has exercised reasonable care. But if a district has exercised reasonable care it does not need immunity. Immunity is ineaningless unless the district would otherwise be liable because of its negligent conduct. The court's statutory interpretation coinpletely robs the statute of any force; section 44808 would never grant immunity under its approach.

The court's interpretation of the final statutory clause also renders the preceding clauses redundant. If the final clause withdraws immunity every time $e^{35}$ the school district fails to exercise reasonable supervisorial care, there is no need for the statute to list particular occasions when immunity is withdrawn. The court's holding violates the rule of statutory interpretation that the various portions of a statute should be interpreted as a whole, and that interpretations that make words or clauses surplusage are to be avoided. ${ }^{36}$

The court sought to bolster its reliance on the "reasonable care"

34. CAL. Educ. CoDE $\S 44808$ (West 1978). A second paragraph provides: "In the event of such a specific undertaking, the district, . . . shall be hable or responsible for the conduct or safcty of any pupil only while such pupil is or should be under the immcdiate and direct supervision of an cmployee of such district." $I d$.

35. 22 Cal. 3d at 517, 585 P.2d at 856, 150 Cal. Rptr. at 6.

36. Palos Verdes Faculty Ass'n v. Palos Verdes Peninsula Unified School Dist., 21 Cal. 3d 650, 659, 580 P.2d 1155, 1159, 147 Cal. Rptr. 359, 363 (1978). 
exception by asserting that the clause was not part of the original bill, but was added by amendment. The court argued that this demonstrated a legislative intent that "when a school district fails to exercise reasonable care the immunity of this section evaporates." ${ }^{37}$ The court was not, however, accurate in its description of section 44808's genesis. The Senate amendment to which the court referred did not "add" the "reasonable care" clause, but instead moved the phrase from the end of the second paragraph to the end of the first paragraph. ${ }^{38}$ In its original position the phrase was intended clearly to limit school district liability, ${ }^{39}$ so that liability would ouly attach if a school negligently supervised one of the enumerated undertakings. The bill's sketchy legislative history does not disclose whether the final shift in language was intended as a purely cosmetic change, or whether a substantive change was desired. ${ }^{40}$

If a substantive change was intended, the legislature may have moved the "reasonable care" clause for either or both of two reasons. First, section 44808 seems to evidence a legislative intent to shield school districts from liability for off-campus supervisorial negligence. For example, schools are not hable under the statute for failing to supervise students on their way to and from school, if no school transportation is provided. ${ }^{41}$ But if a truck driver employed by a school district were negligently to run over a student walking to school, a literal reading of the first paragraph of the statute without the "reasonable care" clause would extend immunity for such an accident. Since the truck driver's action is nonsupervisorial negligence, and since the legislature presumably did not intend to provide immunity in such circunistances, the "reasonable care" clause should be viewed as limiting the statutory immunity to cases of supervisorial negligence.

Second, the clause inay have been noved in order to deny immu-

37. 22 Cal. $3 \mathrm{~d}$ at $517 \mathrm{n} .2,585$ P.2d at $856 \mathrm{n} .2,150$ Cal. Rptr. at $6 \mathrm{n} .2$.

38. The "reasonable care" phrase was initially placed at the end of the statute's second paragraph:

In the event of such a specific undertaking, the district . . . shall be hable or responsible for the conduct or safety of any pupil only while such pupil is or should be under the immediate and direct supervision of an employee of such district . . ., and the entity or person has failed to exercise reasonable care under the circumstances.

CAL. SEN. J., July 12, 1972, at 5202. Before enactment, the italicizcd portion was moved to the end of the first paragraph. CAL. SEN. J., July 31, 1972, at 6247.

39. Without the "reasonable care" phrase, the second paragraph might appear to inupose strict hability for all student injuries incurred while pupils were under off-campus supervision, even if the supervision were entirely proper.

40. "It is a settled principle of statutory construction that a material change in the phraseology of a legislative enactment is ordinarily viewed as showing an intention on the part of the legislature to change the meaning of the statute." McDonough Power Equip. Co. v. Superior Court, 8 Cal. 3d 527, 534 n.5, 503 P.2d 1338, 1342 n.5, 105 Cal. Rptr. 330, 334 n.5 (1972). The question remains whether the movement of the "reasonable care" phrase was a material change.

41. See 22 Cal. 3d at 517, 585 P.2d at 856, 150 Cal. Rptr. at 6. 
nity in situations that are analogous to the listed exceptions but are not specifically enumerated. For example, a school might ask a parent to transport children when reasonable care would have disclosed that the parent was an unfit driver. ${ }^{42}$ This situation would be very like the situation in which the school itself provides transportation and is not iminune from liability for negligence. The "reasonable care" clause could be imterpreted to deny immunity in such analogous, unspecified situations.

Another deficiency in the court's statutory interpretation is its failure to read the clause im the context of the entire statute's wording. All of the statutory exceptions to immunity prior to the "reasonable care" clause are aimed at removing immunity when a district has specifically exercised control or responsibility over students while off-campus. The paragraph immediately following the statute's listed exceptions to immunity begins, "In the event of such a specific undertaking . . . ."43 The listed exceptions to immunity occur only in situations where the school district has sought off-campus control or responsibility. ${ }^{44}$ Yet, the majority asserted that the statutory immumity disappears regardless of whether the school district has sought off-campus responsibility.

The court also felt that the "decisional history" precedmg the statute's enactment supported its reading of legislative imtent, and that the primary concern of the legislature had been to limit a school district's liability for injuries incurred outside of school hours while students were traveling to and froni school. ${ }^{45}$

This interpretation is questionable, masmuch as it relies ${ }^{46}$ on cases decided in the $1950^{\prime} \mathrm{s}^{47}$ to prove that in 1972 the legislature passed section 44808 with the principal intent of shielding school districts from hability for student injuries incurred while traveling between school and home. In Kerwin v. County of San Mateo, the court of appeal held

42. See Hanson v. Reedley Joint Union High School Dist., 43 Cal. App. 2d 643, 111 P.2d 415 (4th Dist. 1941) (school district liable for injuries where tennis coach arranged for student, known to be a reckless driver with a dangerous car, to drive other students home after practice).

43. CAL. EDuc. CoDE $\S 44808$ (West 1978) (emphasis added).

44. Witkin, in his description of $\$ 44808$, confirms that the only occasion school district liability attaches is when "(a) there has been an undertaking to provide transportation to and from school or to sponsor a school activity off school premises, or (b) responsibility or liability has been "otherwise specifically assumed." 4 B. WITKIN, SuMMARY OF CALIFORNia LAW \$ 95, at 2398 (8th ed. 1974) (emphasis in original). The "reasonable care" clause is not mentioned by Witkin, apparently indicating his behef that the clause does not change the statute's force and applieation.

45. $22 \mathrm{Cal} .3 \mathrm{~d}$ at 517,585 P.2d at $856,150 \mathrm{Cal}$. Rptr. at 6.

46. Id. at 517-18, 585 P.2d at 856-57, 150 Cal. Rptr. at 6-7.

47. Kerwin v. County of San Mateo, 176 Cal. App. 2d 304, 1 Cal. Rptr. 437 (1st Dist. 1959) (no liability for injury to eleven-year-old boy, not a student at the school, who was injured while escorting his ill six-year-old brother home); Girard v. Monrovia City School Dist., 121 Cal. App. 2d 737, 264 P.2d 115 (2d Dist. 1953) (no liability for negligently enrolling student in the wrong school, causing him to cross very busy streets where he was injured on his way home from school). 
that "[a] school district is under no duty to supervise, or provide for the protection of its pupils, on their way home, unless it has undertaken to provide transportation for them." 48 The Hoyem court asserted that the legislature "borrowed" this language from Kerwin in drafting section 44808 , thus evidencing an intent to limit the statute's immunity to similar school-to-home travel circumstances. ${ }^{49}$ However, if the legislature was "borrowing" language from Kerwin, it could easily have duplicated the "on their way home" phrase. Instead, the language preceding the exceptions is sweeping in that there is no liability "at any time when such pupil is not on school property."

Section 44808 was proposed and passed two years after the Dailey decision reaffirmed the duty of school districts to use reasonable care im supervising students on-campus. In its origmal form the section 44808 bill provided immunity for off-campus and certain on-campus imjuries for which districts would otherwise have been liable under Dailey. ${ }^{50}$ This suggests that the bill was imtroduccd, in part at least, to limit the effect of Dailey, contrary to the Hoyem court's assertion that the statute was principally motivated by the legislature's desire to codify older cases.

Adıittcdly, the statute was poorly drafted. Rather than seizing on a particular phrase $\mathrm{m}$ it to the detriment of an overall interpretation, however, the Hoyem court should have used the evidence from the circumstances surrounding the statute's passage, ${ }^{51}$ and concluded that any off-campus imjury occurring because of the school district's supervisorial negligence, with the exceptions of the enumerated specific undertakings or analogous situations, would not be actionable. The duty to warn agamst truancy and other unsafe activities would be unaffected. School districts would still be liable for all off-campus injuries occurring because of nonsupervisorial negligence. This interpretation is con-

48. 22 Cal. 3d at 518, 585 P.2d at 856, 150 Cal. Rptr. at 6 (emphasis added by the Hoyem court) (quoting $176 \mathrm{Cal}$. App. 2d at 307, 1 Cal. Rptr. at 439).

49. 22 Cal. $3 \mathrm{~d}$ at 518,585 P.2d at $856,150 \mathrm{Cal}$. Rptr. at 6 . The only language that the statute has in common with the Kerwin language is the phrase "has undertaken to provide transportation."

50. Section 44808, as originally introduced by Assemblyman Chappie, read in part: No . . . school district . . . shall be . . . liable for the conduct or safety of any pupil of the public schools at any time when such pupil is not on school property or, if on school property, while not under the immediate and direct supervision of a certificated employee of a school district.

CAL. Assem. J., March 15, 1972, at 1000. The proposed bill would have limited Dailey by allowing district hability only when students were under "immediate and direct" supervision.

51. The Hoyem majority did not explain why the legislature would have intended to allow neghigently supervised truants to recover daunages under $\$ 44808$, while negligently supervised students on nonrequired excursious are barred from recovery under CAL. EDUC. CODE $§ 35330$. See Castro v. Los Angeles Bd. of Educ., 54 Cal. App. 3d 232, 126 Cal. Rptr. 537 (2d Dist. 1976). 
sistent with what can be gleaned from the circumstances surrounding the statute's passage.

\section{IV}

\section{Legislative Alternatives}

The potential for neghigent supervision by school authorities does not necessarily require that there be accompanying monetary liability. ${ }^{52}$ The Hoyem court's objective to provide an incentive for reasonable truancy prevention could be addressed legislatively in a manner less likely to cause such severe costs to schools. For example, administrative sanctions could be imposed on teachers failing to provide proper supervision. Sanctions could consist of fines, suspensions, reassignments, or even disinissal. If these sanctions were actively enforced, school authorities would be unlikely to ignore the truancy problem.

The legislature could also clarify the monetary incentive to prevent truancy that already exists under state law. School districts in California are apportioned state funds on the basis of the number of pupils in average daily attendance (ADA). Students inust be under the immediate supervision and control of school officials during the school day in order to be included in the attendance figures. ${ }^{53}$ The Legislative Counsel of California has concluded that schools may not report a student in attendance for ADA apportionment purposes if the student leaves school without permission before completing the mininum school day. ${ }^{54}$ If this policy were enforced, school districts would strive to prevent truancies in order to prevent the loss of state ADA funds. Schools would have a monetary incentive to prevent truancies, but the econornic consequences would not be as potentially crippling as is the liability that districts now face under Hoyem.

If monetary hability is considered essential, the legislature should limit recovery to truants ${ }^{55}$ injured because of the intentional misconduct of supervising teachers. For example, if a teacher watched a student leave campus, with knowledge the student did not have

52. Cf. Borer v. American Airlines, Inc., 19 Cal. 3d 441, 446-47, 563 P.2d 858, 862, 138 Cal. Rptr. 302, 306 (1977) (quoting Suter v. Leonard, 45 Cal. App. 3d 744, 746, 120 Cal. Rptr. 110, 11112 (2d Dist. 1975)): "[N]ot every loss can be made compensable in money damages. . . . [T] courts must locate the line between liability and nonliability at some point, a decision which is essentially political."

53. Cal. Educ. Code $\S \S 46010(a), 46300$ (a) (West 1978).

54. Office of the Auditor General, Report to the Joint Legislative Audit Committee, Attendance and Absenteeism in California Schools, Appendix B (March 1979) (Letter of Bion M. Gregory, Legislative Counsel of California). See 5 CAL. ADMIN. CoDE $\$ 405$ (1977).

55. The legislature should define the term "truant" to mean students who knowingly leave campus without permission. Cf. CAL. Educ. CODE $\$ 48260$ (West 1978). School officials would still have the relatively easy duty to prevent very young students, who could not have any wrongful intent, from wandering away. 
permission to leave, liability should attach if no attempt were made to stop the student. By limiting liability to this sort of lapse in pupil containment, schools could know with relative certainty what kind of conduct would be actionable. There is inherent uncertainty in the court's "reasonable care" standard that may result in erratic jury verdicts. More importantly, this uncertainty may encourage schools to be overzealous in securing campuses, thereby damaging the educational process. A requirement that plaintiffs prove that the school district ignored actual notice of threatened truancy would help to provide the predictability that is lacking under the "reasonable care" standard.

\section{CONCLUSION}

The Hoyem decision is significant for several reasons. First, despite the majority's statements to the contrary, the decision imposes a new duty on school districts: ${ }^{56}$ the duty to try to prevent students from surreptitiously leaving campus. The court does not acknowledge that the level of school supervision historically needed to discharge the school's duty to prevent on-campus injuries may now, in many cases, be neghigent im the context of a duty to contain truants.

Second, Hoyem is a disturbing example of the court's approach to statutory interpretation. The court seized on the "reasonable care" clause, removed it from its context within Education Code section 44808 , and nullified the entire effect of the statute.

Finally, the imposition of monetary liability has the potential for

56. See Levy \& Ursin, supra note 3, at 544 n. 248.

The legislature's response to the Hoyem decision was the introduction of California State Senate Bill 60, on December 5, 1978, a little over one month after Hoyem was decided.' The bill, which would amend CAL. EDuc. CODE $\S 44808$, has gone through an interesting metamorphasis. As originally introduced, the bill would have added a paragraph to $\$ 44808$ precluding liability "for the conduct or safety of any pupil of the public schools not on scliool property without the permission of a school officer or employee during such pupil's prescribed school hours." CAL. SEN. J., Dec. 5, 1978, at 20. In the initial anendment the bill's grant of immunity becanie conditioned on reasonable notification to parents (after discovery of the truancy) that their child had left school property. CAL. SEN. J., Feb. 16, 1979, at 568. This condition was then eliminated and the bill was essentially returned to its original forn. CAL. SEN. J., May 9, 1979, at 3044-45. An additional paragraph was then added, emplrasizing the duty of school personnel to (1) follow pupil attendance procedures pursuant to state law, and (2) exercise reasonable care "to assure the continued presence of [students] on school grounds during school hours." CAL. AssEM. J., July 11, 1979, at 7845. The second duty was later deleted. CAL. Assem. J., Jan. 14, 1980, at 10530.

S.B. 60 is significant for two reasons. First, in none of the bill's forms has the legislature removed the "reasonable care" exception that the Hoyem court felt denied immunity when school negligence allowed truancy to occur. The bill's supporters evidently feel the "reasonable care" clause is not inconsistent with a grant of immunity for injuries to truants. Second, S.B. 60 grants district inmunity in Hoyem-type cases, yet still requires that school personnel follow pupil attendance procedures. The bill's supporters apparently feel that monetary liability is not essential to imsure reasonable supervision by school personnel. This suggests that administrative sanctions are considered sufficient to deter negligent supervision. 
significantly affecting school finances. Whether Hoyem-type claims will arise in significant numbers is uncertain, ${ }^{57}$ but even a small number of suits may result in substantial judgments against school districts. And apart froin the quantity of school funds that may be lost in such judgments, the decision's most significant financial impact may be that many districts will feel compelled to alter their budgetary priorities so that less is spent on instruction and nore on containment.

Albert T. Harutunian III*

57. A few Hoyem-like cases were pending in California at the time Hoyem was argued. Letter from Roberta M. Fesler, Deputy County Counsel, County of Los Angeles (April 20, 1979) (on file at Califormia Law Review). According to one estimate, "on the high school level somewhere between 1-6\% of the students attending morning classes will "cut' their afternoon classes." Note, supra note 27 , at 1916 n.170. There are no figures as to what percentage of truants become injured.

Aside from the threat of substantial money awards in this type of case, what inay be of even greater importance to school districts is the abrogation by Hoyem of their previous practice of simply demurring to suits by injured truants. Letter from C.H. Allen, Insurance Supervisor, Los Angeles Unified School District (May 29, 1979) (on file at California Law Review). The costs of discovery and trial preparation im all cases, meritorious or not, could be substantial.

* B.A. 1977, Claremont Men's College; J.D. 1980, Boalt Hall School of Law, University of California, Berkeley. 